\title{
STUDY OF GILL, KIDNEY, AND LIVER STRUCTURE OF Pangasius hypophthalmus IN THE TANJUNG KUDU LAKE AND SAIL RIVERS, RIAU PROVINCE
}

\author{
Christin Irene $^{1}$, Eddiwan ${ }^{1}$, Windarti $^{1}$ \\ ${ }^{1}$ Department of Aquatic Resources Management, Faculty of Fisheries and Marine \\ Universitas Riau, Pekanbaru \\ *christin.irene3862@student.unri.ac.id
}

\begin{abstract}
Environmental condition and water quality in general may affects the health status of fish and it represents in the structure of fish organs such as the gill, kidney, and liver. To understand the structure of the gill, kidney, and liver of Pangasius hypophthalmus that live in the Tanjung Kudu Lake (good water quality) and in the Sail River that has been polluted, a study has been conducted from November to December 2020. Twelve fishes (6 fishes/river) were analyzed. The tissue was formalin-fixed and processed through alcohol series, paraffinembedded, $5 \mu$ sliced and Hematoxylin-Eosin stained. The histological samples were then studied using a binocular microscope Olympus CX 21. The abnormality level of the tissue was categorized using the Histopathological Alteration Indeks (HAI). Results showed that the fish tissues from both study sites indicate light abnormality signs such as hyperplasia, hypertrophy, and lifted epithelia. The HAI was 2 for fish from the Tanjung Kudu Lake and 3 for the fish from the Sail River. This index indicates that the abnormality may be cured as the water quality improved.
\end{abstract}

Keywords: Histological Structure, Histopathological Alteration Indeks, Tanjung Kudu Lake, Sail River

\section{PENDAHULUAN}

Ikan patin jambal (Pangasius hypophthalmus) merupakan ikan yang banyak dijumpai di Riau. Ikan ini dijumpai di Danau Tanjung Kudu dan Sungai Sail. Danau Tanjung Kudu merupakan danau oxbow yang terdapat di Kabupaten Kampar tepatnya di Desa Kualu Kecamatan Tambang. Danau Tanjung Kudu merupakan danau oxbow yang terbentuk akibat terputusnya aliran sungai Kampar Kanan. Berbagai aktifitas terdapat di Danau Tanjung Kudu misalnya adanya penangkapan ikan oleh penduduk sekitar, adanya vegetasi dan pepohonan di sekitar tepian danau. Akan tetapi kondisi perairan dari Danau Tanjung Kudu ini masih dapat dikatakan baik karena pencemaran yang terdapat didanau ini hanya bahan organik saja yang tidak berpengaruh terhadap kerusakan jaringan insang, ginjal, dan hati pada ikan.

Ikan patin jambal juga dijumpai pada perairan yang tercemar seperti Sungai Sail. Secara visual keadaan Sungai Sail dikategorikan tercemar. Hal ini dilihat dari warna air sungai cokelat serta memiliki aroma atau bau air tidak sedap. Selain itu permukaan sungai terdapat sampah-sampah seperti botol bekas minuman, plastik bekas detergen, bungkus makanan, rantingranting pohon dan sampah lainnya.

Perbedaan kondisi kedua perairan tersebut diperkirakan mengakibatkan 
perbedaan kondisi kesehatan ikan. Kondisi kesehatan ikan tergambar pada struktur jaringan insang, ginjal dan hati ikan. Insang merupakan organ yang rentan terhadap perubahan lingkungan karena insang langsung bersentuhan dengan air. Selain itu, ginjal sebagai organ yang menyaring semua bahan sebelum dialirkan ke tubuh sehingga apabila kondisi lingkungan mengandung banyak bahan toksik menyebabkan kerusakan pada ginjal.

Bila ada racun/ toksik dalam air maka yang berperan penting untuk menetralisir atau mengeluarkan racun yang masuk kedalam tubuh yaitu hati. Sebelum materi toksik/racun masuk ke dalam tubuh suatu organisme, materi tersebut akan diolah oleh hati sehingga tidak lagi membahayakan bagi organisme tersebut. Oleh karena itu kondisi hati sangat erat kaitannya dengan kondisi lingkungan di mana ikan tersebut hidup [1]. Adanya perbedaan kondisi lingkungan Danau Tanjung Kudu dan Sungai Sail diduga dapat menyebabkan perbedaan kondisi insang, ginjal, dan hati ikan yang ada di kedua danau tersebut.

Sejauh ini belum ada penelitian dan informasi tentang struktur jaringan insang, ginjal, dan hati ikan patin jambal di Danau Tanjung Kudu dan Sungai Sail. Oleh karena itu peneliti tertarik untuk melakukan penelitian mengenai perbandingan struktur jaringan insang, ginjal, dan hati pada ikan patin jambal di Danau Tanjung Kudu dan Sungai Sail.

Penelitian ini bertujuan untuk mengetahui perbedaaan struktur jaringan insang, ginjal, dan hati ikan patin jambal yang hidup di Danau Tanjung Kudu dan Sungai Sail Provinsi Riau.

\section{METODE PENELITIAN}

Waktu dan Tempat

Penelitian ini telah dilaksanakan pada bulan November-Desember 2020 dan tempat pengambilan sampel adalah dari Danau Tanjung kudu dan Sungai Sail. Pembuatan preparat dan pengamatan preparat insang, ginjal, dan hati ikan patin jambal di Laboratorium Biologi Perairan Fakultas Perikanan dan Kelautan Universitas Riau.

\section{Metode Penelitian}

Ikan sampel diambil dari Danau Tanjung Kudu dan Sungai Sail. Pembuatan preparat struktur jaringan insang, ginjal, dan hati dilakukan menurut [1] dan metode pewarnaan Haematoxylin dan Eosin (HE) menurut [1].

\section{Prosedur Penelitian}

\section{Pengambilan Sampel Ikan Patin Jambal (P. hypophthalmus)}

Sampel ikan segar diperoleh dari hasil tangkapan nelayan di Danau Tanjung Kudu dan Sungai Sail, satu kali dalam seminggu, sebanyak tiga kali ulangan. Penangkapan ikan menggunakan jala dan jaring.

\section{Pembuatan Preparat Struktur Jaringan Ikan Patin Jambal (P. hypophthalmus)}

Pembuatan preparat organ insang, ginjal dan hati dilakukan menurut [1]. Sampel organ difiksasi dengan formalin $10 \%$ selama 24-48 jam dan dipindahkan ke formalin $4 \%$ dan selanjutnya diproses untuk pembuatan preparat histologi dengan cara rehidrasi dengan penggunaan alkohol bertingkat, penanaman dalam parafin dan pemotongan dengan ketebalam 5 mikron. Kemudian sampel diwarnai dengan menggunakan Haematoxylin dan Eosin (HE). Preparat diamati atau difoto dengan menggunakan mikroskop Olympus CX21. Parameter yang diamati adalah lebar lamella sekunder, jarak antara lamella sekunder serta kelainan-kelainan yang ada pada insang, ginjal, dan hati ikan tersebut.

\section{Analisis Data}

Tingkat kerusakan struktur jaringan insang dihitung dengan menggunakan Histopathological Alteration Indeks (HAI) menurut [1]. Nilai HAI dihitung untuk 
setiap individu ikan dengan rumus sebagai berikut:

$$
\mathrm{HAI}=\left(1 \mathrm{X} \sum I\right)+\left(10 X \sum I I\right)+\left(100 X \sum I I I\right)
$$

\section{Keterangan:}

- Angka 1, 10, dan 100 adalah skor nilai untuk masing-masing tingkat atau golongan kerusakan jaringan.

- I, II dan III tingkat golongan kerusakan insang

- $\quad$ Sadalah jumlah jenis kerusakan insang pada setiap golongan atau tingkat kerusakan insang yang dijumpai pada setiap ikan.

- Untuk mendapat nilai HAI, maka skor untuk masing-masing kategori kerusakan jaringan insang dijumlahkan.

- Bila jumlah sampel banyak, maka nilai HAI dari sampel tersebut merupakan rata-rata dari nilai HAI masing-masing individu ikan.

Nilai Histopalogical Alteration Index (HAI) menurut [1]:

$$
\begin{aligned}
0-10= & \text { fungsi organ normal } \\
11-20= & \text { organ mengalami kerusakan } \\
& \text { ringan } \\
21-50= & \text { organ mengalami kerusakan } \\
& \text { sedang } \\
51-100= & \text { organ mengalami kerusakan } \\
& \text { berat } \\
>100= & \text { organ tidak dapat dipulihkan } \\
& \text { kembali }
\end{aligned}
$$

\section{HASIL DAN PEMBAHASAN} Keadaan Umum Lokasi Penelitian

Kondisi lingkungan perairan Danau Tanjung Kudu dan Sungai Sail, di mana sampel ikan diambil, memiliki perbedaan. Kondisi permukaan Danau Tanjung Kudu relatif tenang dan memiliki dasar perairan yang bersubstrat, berpasir, dan berlumpur yang memiliki warna air kuning kecoklatan. Sedangkan Sungai Sail memiliki warna air cokelat keruh diduga karena adanya aktifitas pembuangan limbah yang berlebihan ke badan air, selain itu juga terdapat sampah di pinggiran dan di dalam aliran sungai yang mengakibatkan air menjadi berbau.

Aktifitas di sepanjang Danau Tanjung Kudu dan Sungai Sail berbeda. Di Danau Tanjung Kudu berupa penangkapan ikan oleh penduduk sekitar, adanya vegetasi dan pepohonan di sekitar tepian danau. Sedangkan di Sungai Sail terdapat banyak aktivitas seperti menjala dan memancing serta penangkapan cacing sutera atau Tubifex sp. sebagai pakan alami untuk ikan. Sedangkan kegiatan yang mempengaruhi berupa limbah yang berasal dari pemukiman penduduk, pasar, lahan pertanian dan peternakan, aktifitas rumah potong hewan, pengetaman kayu dan lain sebagainya.

\section{Hasil Tangkapan Ikan Patin Jambal}

Ikan patin jambal yang dijadikan sampel selama penelitian berjumlah 40 ekor, kemudian sampel tersebut diambil sebanyak 12 ekor dan masing masing 6 ekor dari kedua perairan tersebut untuk dianalisis secara histologi. Sampel ikan patin jambal dari Danau Tanjung Kudu memiliki kisaran panjang total (TL) 270$428 \mathrm{~mm}$, panjang baku (SL) 170-370 mm dan berat 150-260 g. Sedangkan Sungai Sail memiliki kisaran panjang total (TL) 330-462 mm panjang baku (SL) 280-390 $\mathrm{mm}$ dan berat $440-850 \mathrm{~g}$.

\section{Morfologi Ikan Patin Jambal}

Ciri-ciri morfologi ikan patin jambal yang tertangkap dalam penelitian ini adalah sebagai berikut, ikan patin jambal memiliki bentuk tubuh yang memanjang, bentuk kepala pipih dan pendek, bentuk mulut agak kebawah (subterminal) dan tidak dalat disembulkan, memiliki dua pasang sungut, tidak bersisik di seluruh tubuhnya, punggung lebih berwarna hitam keabuabuan serta memiliki garis-garis hitam lengkung memanjang dari kepala hingga pangkal ekor [2]. 
Perbedaan Ikan Patin Jambal dari Danau Tanjung Kudu dan Sungai Sail

Hasil penelitian menunjukkan bahwa ikan patin jambal yang didapatkan dari Danau Tanjung Kudu agak berbeda sedikit dari Sungai Sail. Dari segi ukuran, ikan patin jambal yang terdapat di Sungai Sail memiliki ukuran yang lebih besar dibandingkan dengan ikan patin jambal dari Danau Tanjung Kudu.

Ikan patin jambal yang terdapat di Sungai Sail lebih gemuk dari pada ikan patin jambal yang terdapat di Danau Tanjung Kudu. Bentuk tubuh ikan patin jambal di Sungai Sail sedikit berwarna biru gelap, hal ini diduga dikarenakan warna air yang cokelat dan keruh. Menurut [3], perubahan warna tubuh ikan dipengaruhi oleh perubahan faktor lingkungan yang menyebabkan ikan menjadi stress. Umumnya ikan yang stress akan memiliki warna tubuh yang gelap dan menghasilkan lendir yang berlebih. Namun, apabila dilihat dari panjang berat, ikan patin siam dari Sungai Sail memiliki berat lebih besar dari pada ikan patin jambal di Danau Tanjung Kudu (Gambar 1).

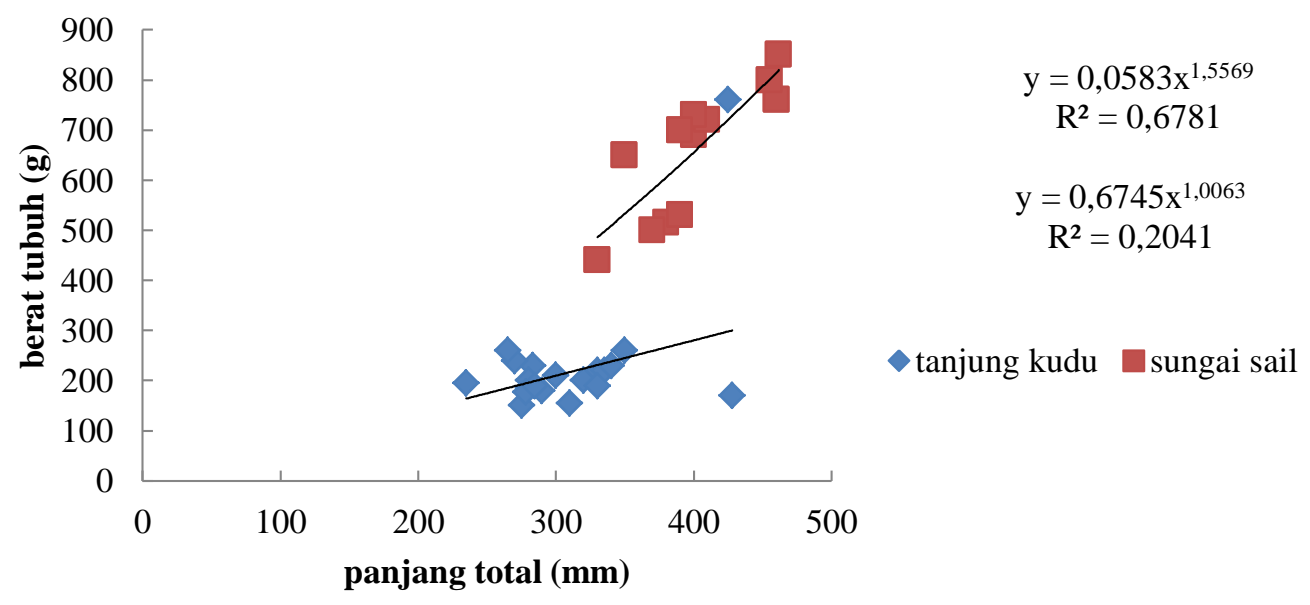

Gambar 1. Hubungan Panjang Total dan Berat Ikan Patin Jambal dari Danau Tanjung Kudu dan Sungai Sail

Gambar 1 diketahui bahwa hubungan panjang berat ikan patin jambal di Danau Tanjung Kudu dan Sungai Sail berbeda. Hubungan panjang berat ikan patin jambal di Danau Tanjung Kudu bersifat allometrik negatif dengan nilai $\mathrm{b}=1,00$ dan ikan patin jambal di Sungai Sail bersifat allometrik positif dengan nilai $b=1,55$. Berdasarkan hubungan panjang berat tersebut dapat diketahui bahwa ikan patin jambal di Sungai Sail lebih gemuk dari pada ikan patin jambal di Danau Tanjung Kudu. Gemuknya ikan patin jambal di Sungai Sail diduga karena Sungai Sail terdapat berbagai aktifitas pemukiman penduduk, pasar, lahan pertanian dan peternakan, aktifitas rumah potong hewan, pengetaman kayu dan lain sebagainya. Tingginya materi organik di perairan menyebabkan organisme kecil menjadi banyak, atau dengan kata lain makanan untuk ikan patin jambal melimpah, sehingga ikan patin jambal menjadi sangat gemuk dari pada ikan patin siam di Danau Tanjung Kudu. Walaupun kecerahan di Sungai Sail dibawah ambang batas tapi tidak mempengaruhi ikan patin jambal dalam mencari makan, dikarenakan ikan patin jambal adalah ikan nocturnal yang beraktifitas pada malam hari [4].

\section{Struktur Jaringan Ikan Patin Jambal}

Struktur jaringan insang ikan patin jambal yang di Danau Tanjung Kudu dengan yang di Sungai Sail menunjukkan hasil yang tidak jauh berbeda. Secara 
umum struktur jaringan insang ikan terdiri dari lamella primer dan lamella sekunder yang tersusun rapi. Lamella sekunder terdiri dari sel pilar, sel klorid dan sel mucus [5]. Insang ikan pada Danau
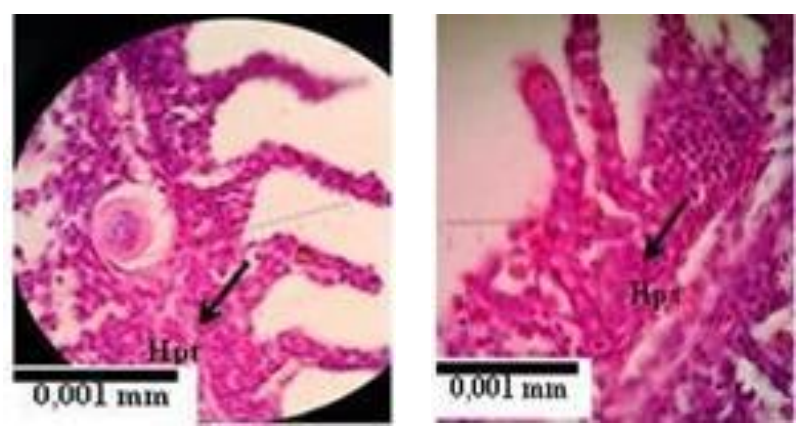

A. Danau Tanjung Kudu

Gambar 2. Struktur Jaringan Insang Ikan Patin Jambal

Keterangan: $\mathrm{Hps}=$ Hyperplasia, $\mathrm{Hpt}=$ Hypertrophy, Ephitelium terangkat
Secara morfologi insang ikan patin jambal di Danau Tanjung Kudu tersebut berwarna merah kehitaman dan berlendir. Struktur jaringan insang ikan patin jambal dari kedua lokasi penelitian tidak jauh berbeda. Secara umum struktur jaringan insang pada ikan patin jambal di Danau Tanjung Kudu menunjukkan abnormalitas seperti hyperplasia dan hypertrophy. Selain itu pada ikan patin jambal di Danau Tanjung Kudu dijumpai parasit spesies Dactylogyrus sp pada insang. Parasit inilah yang memicu terjadinya hyperplasia [6].

Hyperplasia merupakan penambahan dari bagian tubuh atau organ karena adanya peningkatan jumlah sel baru. [7], juga menyatakan bahwa hyperplasia terjadi karena banyaknya sel yang mengalami kerusakan akibat keberadaan parasit pada lamella sekunder yang menjadi faktor utama penyebabnya hyperplasia. Hal ini sesuai dengan pendapat [1], menyatakan bahwa hyperplasia ditandai dengan sel-sel ephitelium yang memperbanyak diri sehingga epidermis menebal dan lamella sekunder satu dengan yang lain bergabung/melebur.

Hyperplasia pada insang mengakibatkan organ insang mengalami iritasi dan mengeluarkan mukus (lendir)
Tanjung Kudu dan Sungai Sail menunjukkan kerusakan yang sama. Kerusakan tersebut terjadi pada lamella sekunder. Kerusakan insang pada ikan patin jambal dapat dilihat pada Gambar 2.
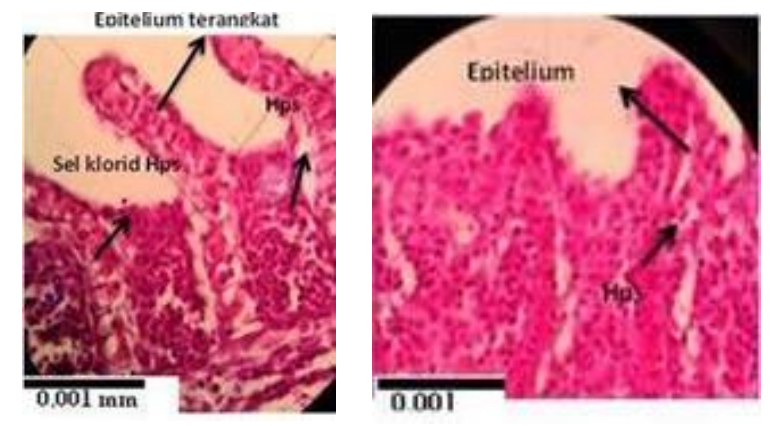

B. Sungai Sail sebagai perlindungan terhadap toksikan timbal, akan tetapi mukus yang dihasilkan justru menutup permukaan lamela insang sehingga pertukaran $\mathrm{O}_{2}$ dan $\mathrm{CO}_{2}$ terhambat, akibatnya tidak ada pengikatan oksigen oleh hemoglobin darah. Sehingga menyebabkan transportasi oksigen ke seluruh tubuh menjadi terganggu [8].

Selain hyperplasia terdapat juga hypertrophy pada ikan patin jambal di Danau Tanjung Kudu. Hypertrophy dapat dilihat dari epitelium yang membesar pada lamella sekunder. Membesarnya epitelium dapat mengakibatkan terganggunya proses penyerapan oksigen di lamella sekunder. Hal ini sesuai dengan pendapat [9] menyatakan bahwa hypertrophy merupakan kerusakan jaringan yang ditandai dengan penambahan ukuran organ akibat bertambahnya ukuran sel sehingga sel yang satu dengan yang lainnya saling lepas.

Secara morfologi insang ikan patin jambal di Sungai Sail tersebut berwarna merah pekat dan berlendir. Gambar 2 menunjukkan bahwa struktur jaringan insang ikan patin jambal di Sungai Sail mengalami abnormalitas seperti, hyperplasia, hypertrophy, dan ephitelium terangkat. Kerusakan yang dijumpai pada 
Sungai Sail hampir sama seperti di Danau Tanjung Kudu.

Ketidaknormalan pada insang di Sungai Sail dapat dilihat dari jumlah sel yang bertambah dan tidak beraturan. Hal ini sesuai dengan pendapat [10], yang menyatakan bahwa pembentukan jaringan secara berlebihan karena bertambahnya jumlah sel. Menurut [11], hyperplasia dikenali dari jaringan yang membengkak dan sudah tidak jelas bentuk struktur sel didalamnya, namun masih mempunyai jaringan epitelium. Hyperplasia yang terjadi secara terus-menerus akan menyebabkan fusi lamella [12]. Selain itu perumbuhan sel yang sangat cepat dan banyak menyebabkan fusi lamella sekunder yang disertai dengan hyperplasia [13]. Fusi lamela yang terjadi akibat hyperplasia sel lamela secara terus menerus mengisi ruang antar lamela sekunder dengan sel baru sehingga menyebabkan perlekatan antar lamela sekunder [14].

Selain hyperplasia, terdapat juga Epithelial lifting atau epitelium terangkat yang di tandai dengan perpindahan lapisan ephitelium yang dapat mengakibatkan terganggunya oksigen. [15] menyatakan bahwa konsekuensi dari peningkatan jarak antara air dan darah karena pengangkatan ephitelium, pengambilan oksigen terganggu. Ephitelium terangkat merupakan perubahan regresif yang paling umum dan diamati pada semua spesies ikan secara vertikal [16].

Kelainan yang mengalami pembengkakan dapat menyebabkan lapisan epithelium terangkat. Ephitelium terangkat adalah pembengkakan ringan sel insang akibat masuknya ion timbal, mengakibatkan timbulnya ephitelium pipih sekunder yang membungkus lamella sekunder yang berfungsi sebagai mekanisme pertahanan [17]. [18] menyatakan bahwa ephitelium terangkat, hyperplasia, dan hypertrophy pada sel klorid adalah lesi umum pada insang dari ikan yang secara eksperimental terpapar tembaga.
Pada penelitian ini dijumpai parasit dengan spesies myxobolus sp. namun tidak pada semua insang. Menurut [19] menyatakan bahwa Insang yang sudah terinfeksi myxobolus dapat menyebabkan nekrosis dan kista pada usus, ginjal. Di insang kerusakan pada tulang rawan juga pembengkakan hati. Pada insang yang terserang myxobolus terdapat pembengkakan kongesti, myxobolus menyerang insang, lengkung insang, dan lamella sekunder [20].

[1] menyatakan bahwa tingkatan/ golongan kerusakan pada jaringan insang dapat dibagi menjadi tiga tingkat, golongan pertama yakni apabila insang hanya mengalami kerusakan ringan yang akan kembali seperti semula apabila lingkungan perairannya sudah membaik seperti hyperplasia, hypertrophy, pelebaran pembuluh darah, deformasi lamella, peleburan lamella, dan kongesti. Golongan kedua yakni, apabila insang ikan mengalami kerusakan yang lebih berat seperti hemoragi, sel mukus sudah tidak ada dan ephitelium pecah. Golongan ketiga yakni apabila insang ikan sudah mengalami kerusakan yang cukup parah sehingga insang ikan tidak dapat lagi kembali seperti semula meskipun lingkungan perairannya sudah membaik, misalnya nekrosis, aneurisma dan telangiectasis. Tingkat kerusakan insang ikan patin jambal pada Danau Tanjung Kudu dan Sungai Sail dapat dilihat pada Tabel 1.

Tabel 1. Kerusakan insang ikan patin jambal dan Nilai HAI

\begin{tabular}{lll}
\hline Kelainan & $\begin{array}{l}\text { Danau } \\
\text { Tanjung } \\
\text { Kudu }\end{array}$ & $\begin{array}{l}\text { Sungai } \\
\text { Sail }\end{array}$ \\
\hline Hyperplasia & $\checkmark$ & $\checkmark$ \\
Hypertrophy & $\checkmark$ & $\checkmark$ \\
Epithelium & & $\checkmark$ \\
terangkat & & \\
Parasit & ada & ada \\
Nilai HAI & $\mathbf{2}$ & $\mathbf{3}$
\end{tabular}


Berdasarkan nilai Histopathological Alteration Index (HAI) pada Tabel 1, tingkat kerusakan jaringan insang ikan patin jambal di Danau Tanjung Kudu dan Sungai Sail ini masih dikategorikan ringan, mendekati normal. Artinya apabila kualitas perairan di Danau Tanjung Kudu dan Sungai Sail dapat pulih atau membaik maka kerusakan jaringan insang ikan patin jambal akan normal kembali atau sembuh.

\section{Struktur Jaringan Ginjal Ikan Patin Jambal}

Struktur jaringan ginjal ikan patin jambal di Danau Tanjung Kudu dan Sungai Sail secara umum menunjukkan hasil yang

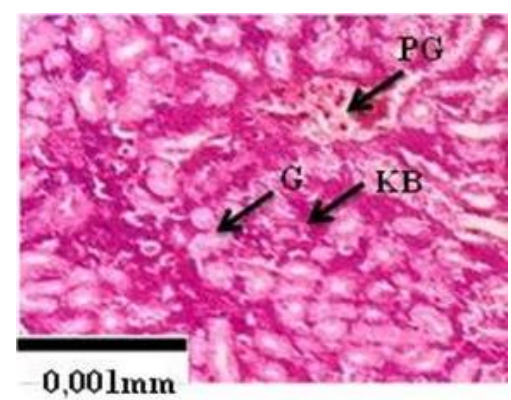

A. Danau Tanjung Kudu tidak jauh berbeda. Struktur jaringan ginjal ikan secara umum tersusun oleh kapsula bowman yang terdapat di dalamnya sel glomerulus. Secara umum, struktur histologi ginjal terdiri dari glomerulus, tubulus, dan pembuluh darah [21]. [22] menyatakan bahwa glomerulus normal secara keseluruhan tertutup oleh kapsula bowman yang berbentuk mangkok. Bila ada toksikan yang masuk ke dalam tubuh, toksikan tersebut akan disaring oleh ikan, tetapi akibatnya seringkali jaringan ginjal menjadi rusak atau mengalami kelainan. Struktur jaringan ginjal ikan patin jambal di Danau Tanjung Kudu dan Sungai Sail dapat dilihat pada Gambar 3

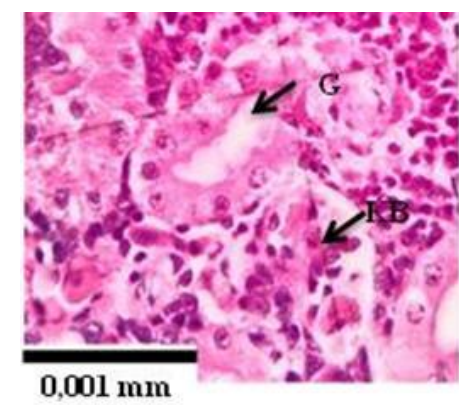

B. Sungai Sail

Gambar 3. Struktur jaringan Ginjal Ikan Patin Jambal Keterangan : $\mathrm{KB}=$ Kapsula Bowman, $\mathrm{G}=$ Glomerulus

Struktur jaringan ginjal ikan patin di Danau Tanjung Kudu dan Sungai Sail hampir sama. Pada gambar tampak kapsul bowman mengelilingi glomerulus, bentuk glomerulus tampak nyata dan tidak bulat. Hal ini menunjukkan bahwa ginjal dalam keadaan normal. Hal ini sesuai dengan pendapat [22], yang menyatakan bahwa glomerulus dalam keadaan normal secara keseluruhan tertutup oleh kapsul bowman yang berbentuk mangkok, kapiler glomerulus dilapisi oleh sel-sel endotel.

\section{Struktur Jaringan Hari Ikan Patin Jambal}

Struktur jaringan hati ikan patin jambal di Danau Tanjung Kudu dan Sungai Sail secara umum menunjukkan hasil yang tidak jauh berbeda. sel-sel hati tampak bagus dan tidak menunjukkan kelainan. Hati merupakan organ yang sangat rentan terhadap pengaruh zat kimia dan menjadi organ sasaran utama dari efek racun zat kimia (toksikan). Struktur jaringan hati ikan secara umum terdiri dari sel hepatosit. Berdasarkan penelitian yang dilakukan struktur jaringan hati ikan patin jambal dapat dilihat pada Gambar 4.

Ikan patin jambal di danau tanjung kudu dan sungai sail memiliki struktur jaringan hati yang hampir sama. Sel hepatosit tampak jelas dengan ini yang bulat. [23] menyatakan bahwa pada hati normal, sel hepatosit terlihat jelas inti bulan dan letaknya sentralis dan sinusoid tampak jelas dan vena sentralis sebagai pusat lobules tampak berbentuk bulat dan kosong. 


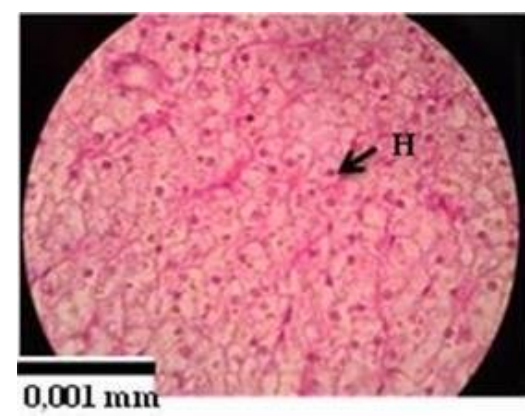

A. Danau Tanjung Kudu

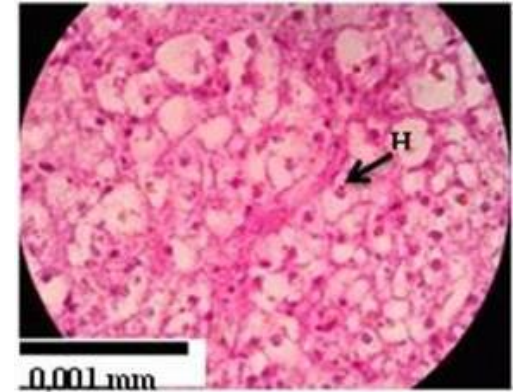

B. Sungai Sail

Gambar 4. Struktur jaringan Hati Ikan Patin Jambal Keterangan : $\mathrm{H}=$ Hepatosit

Struktur jaringan hati ikan patin jambal di Danau Tanjung Kudu dan Sungai Sail menunjukkan tidak adanya kelainan atau kerusakan pada hati yang di sebabkan oleh zat toksik. Masuknya zat toksik ke dalam struktur jaringan hati biasanya disebabkan oleh kerusakan ginjal yang tidak berfungsi dengan baik dalam menyaring zat toksik yang masuk ke dalam tubuh ikan. Akibatnya zat toksik yang menyebar ke organ lain dalam tubuh ikan salah satunya adalah hati [24]. Pada struktur jaringan hati ikan patin jambal di Danau Tanjung Kudu dan Sungai Sail tidak mengalami kerusakan dan masih berfungsi dengan baik.

Tetapi ada satu ikan yang menunjukkan kelainan pada struktur ginjal serta hatinya. Kelainan tersebut berupa pigmentasi. Pigmen tersebut nampak berada di dalam sel dan tersebar di jaringan hati serta ginjal ikan tersebut (Gambar 5). Granula pigmen tersebut nampak berwarna kecoklatan dan tidak menyerap warna baik hematoksilin maupun eosin yang digunakan untuk mewarnai sampel jaringan. Kemungkinan pigmen tersebut termasuk pada jenis pigmen lipofuscin.

Menurut [25] lipofuscin adalah pigmen yang dibentuk oleh lipid, logam, dan protein yang sangat melimpah di sel saraf, sel otot jantung, dan kulit. Lipofuscin menggambarkan pola penuaan tertentu baik dalam keadaan fisiologis maupun patologis, mengubah sitoskeleton neuronal dan perdagangan serta metabolisme seluler, dan dikaitkan dengan hilangnya neuron, serta proliferasi. Jadi kemungkinan ikan yang mempunyai pigmen lipofuscin di dalam jaringan hati dan ginjalnya adalah ikan yang sakit atau mengalami tekanan dalam hidupnya. Menurut [26] pembentukan lipofuscin terjadi bila proses pembentukan lipofuscin tergantung pada peroksidasi lipid dan mampu dihentikan oleh antioksidan.

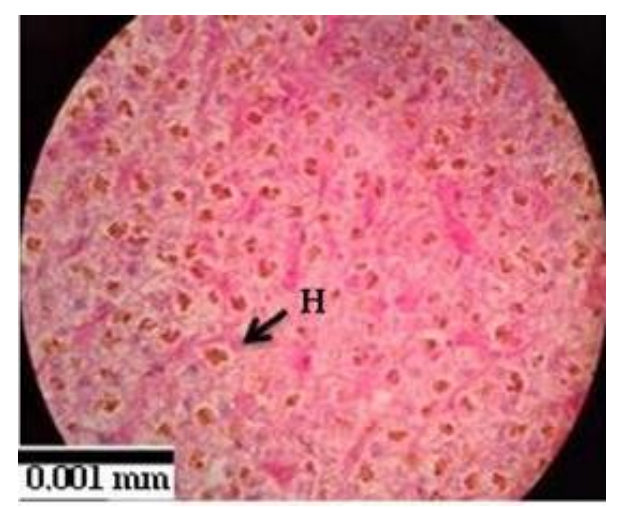

Gambar 5. Kelainan ginjal ikan

Pigmentasi bukanlah suatu abnormalitas/kelainan. Pigmentasi dapat terjadi karena faktor umur atau pengaruh lingkungan. Hal ini sesuai pendapat [27] yang menyatakan bahwa lipofuskin merupakan karakteristik penuaan dini yang dipengaruhi oleh faktor internal seperti umur, dan genetika. Artinya tidak ada zat toksik yang masuk ke dalam struktur jaringan hati ikan patin jambal sehingga tidak menimbulkan kerusakan pada jaringan hati. 


\section{KESIMPULAN DAN SARAN Kesimpulan}

Pada struktur jaringan ikan patin jambal dari Danau Tanjung Kudu dan Sungai Sail terdapat kelainan seperti hyperplasia, hypertrophy, ephitelium terangkat dan kelainan tersebut masih tergolong ringan. Sehingga dapat dikatakan bahwa kelainan tersebut tidak membahayakan. Dan ditemukan adanya parasit yang berjenis myxobolus $s p$ dan dactylogyrus sp di kedua lokasi tersebut.

Struktur jaringan ginjal dan hati ikan patin jambal dari Danau Tanjung Kudu dan Sungai Sail menunjukkan glomerulus dan kapsul bowman masih normal. Terdapat satu ikan dengan pigementasi di hati dan ginjal dan diperkirakan ikan tersebut sakit atau mengalami stres. Struktur jaringan ginjal dan hati ikan patin jambal di kedua lokasi tersebut masih sehat dan bagus.

\section{Saran}

Disarankan untuk melakukan penelitian sejenis di lokasi berbeda dan kurun waktu yang lebih lama serta sampel lebih banyak agar dapat memberikan informasi yang lengkap tentang struktur jaringan organ tubuh ikan patin jambal.

\section{DAFTAR PUSTAKA}

1. Windarti, A. H. Simarmata dan Eddiwan. (2017). Buku Ajar Histologi. UR Press. Pekanbaru.

2. Yanda, M. H. Syawal dan M. Riauwaty. (2018). Ectoparasites Distribution of Catfish (Pangasius hypophthalmus) in Fishpond Kuok Village, Bangkinang Barat District, Kampar Regency, Riau Province. Jurnal Online Mahasiswa Fakultas Perikanan dan Ilmu Kelautan, 5: 1-13.

3. Ismail, K. (2016). Kiat Mengatasi Stress pada Ikan. Penerbit Mediatama. Bogor.

4. Suhara, A. (2019) Teknik Budidaya Pembesaran Dan Pemilihan Bibit Ikan Patin (Studi Kasus di Lahan Luas Desa Mekar Mulya, Kec. Teluk Jambe Barat, Kab. Karawang). Jurnal Buana Pengabdian, 1(2): 1-8.

5. Pertiwi, S.L., Zainuddin dan E. Rahmi. (2017). Histological Respiratory System of Snakehead (Channa striata). Jurnal Ilmiah Mahasiswa Veteriner, 1(3):291-298

6. Hardi, E.H. (2015). Parasit Biota Akuatik. Mulawarman University Press. Samarinda

7. Rifqiyati, N., M.J. Luthfi. dan A.N. Miftah. (2017). Gambaran Histologi Insang Ikan Mas Koki (Carassius auratus) yang Terinfeksi Ektoparasit Argulus sp. Jurnal Bionature 18(1): 1-7

8. Susanah, U.A. (2013). Struktur Mikroanatomi Insang Ikan Bandeng di Tambak Wilayah Tapak Kelurahan Tugurejo Kecamatan Tugu Semarang. Journal of Biology \& Biology Education, 5(1): 1-9.

9. Kahfi, K. E., M. Riauwaty., I. Lukistyowati. (2017). Histopathology Liver and Kidney of Clarias Gariepinus that are Fed Simplisia Mangosteen Rind (Garcinia Mangostana L). Jurnal Online Mahasiswa Fakultas Perikanan dan Ilmu Kealutan, 4(1): 1-10

10. Yolanda, S., Rosmaidar, Nazaruddin, T. Armansyah, U. Balqis, dan Y. Fahrima. (2017). The Effect of Lead (Pb) Exposure to the Histopathology of Nile Tilapia (Oreochromis nilloticus) Gill. Jurnal Ilmiah Mahasiswa Veteriner, 1(4):736-741

11. Juanda, S.J., dan S.I. Edo. (2018). Histopatologi Insang, Hati dan Usus Ikan Lele (Clarias gariepinus) di Kota Kupang, Nusa Tenggara Timur. Jurnal Saintek Perikanan, 14(1): 23-29.

12. Indrayani, D., Yusfiati, R. Elvyra. (2014). Struktur Insang Ikan Ompok hypophthalmus (Bleeker, 1846) dari Perairan Sungai Siak Kota Pekanbaru. JOM FMIPA, 1(2) 
13. Lestari, W.P., N.I. Wiratmini, dan A.A.G.R. Dalem. (2018). Histological Structures of Gills of Tilapia Fish (Oreochromis mossambicus L.) as a Water Quality Indicator in the Nusa Dua Sewage Tretment Ponds, Bali. 6(2 ): 45- 49

14. Sipahutar, L. W., D. Aliza, Winaruddin, dan Nazaruddin. (2013). Histopathological Changes of Gills of Nile Tilapia (Oreochromis niloticus) Maintained in Above Normal Water Temperature. Jurnal Medika Veterinaria, 7(1):1920.

15. Camargo, M. M.P., and C.B.R. Martinez. (2007). Histopathology of Gills, Kidney and Liver of a Neotropical Fish Caged in an Urban Stream. Neotropical Ichthyology, 5(3):327-336

16. Lujić, J., Z. Marinović, dan B. Miljanović. (2013). Histological Analysis of Fish Gills as an Indicator of Water Pollution in the Tamiš River. Acta Agriculturae Serbica, 18(36): 3-141.

17. Mulyani, F.A.M. (2014). Uji Toksisitas dan Perubahan Struktur Mikroanatomi Insang Ikan Nila Larasati (Oreochromis nilloticus Var.) yang Dipapar Timbal Asetat. Universitas Negeri Semarang.

18. Movahedinia, A., B. Abtahi, and M. Bahmani. (2012). Gill Histopathological Lesions of the Sturgeons. Asian Journal of Animal and Veterinary Advances, 7: 710-717.

19. Soelistyoadi, R.N., A.D. Nurekawati, dan D. Setyawati. (2020). Morphology and Sequencing of Myxobolus koi DNA that Infects Koi fish (Cyprinus carpio) in Blitar Regency. Journal of Aquaculture Science, 5(1): 38-53.

20. Prihartini, N.C., dan Alfiyah. (2017). Myxosporeasis In Koi (Cyprinus carpio). Samakia: Jurnal Ilmu Perikanan, 8(1): 6-10.

21. Mc Gavin, M. D., dan J.F. Zachary. (2007). Pathologic Basic of Veterinary Disease. Mosby Incorporation, USA.

22. Laily, H., Farikhah, dan U. Firmani. (2018). Analisis Histologis Ginjal, Hati, dan Jantung Ikan Lele Afrika Clarias gariepinus yang Mengalami Anomali pada Sirip Pektoral. Jurnal Perikanan Pantura (JPP), 1(2): 30-38

23. Riauwaty, M. (2013). Histopatology of Liver and Kidney of Pangasius hypophthalmus Infected with Aeromonas hydrophila and are Cured using Curcuma xanthorrhiza Roxb Extract. Repository Unri.

24. Rahayu, N. I., Rosmaidar, M. Hanafiah, T. F. Karmil, T. Z. Helmi, dan R. Daud. (2017) Influence of Lead $(\mathrm{Pb})$ Exposure on the Rate of Growth Tilapia Fish (Oreochromis niloticus). Jurnal Ilmiah Mahasiswa Veteriner, 1(4):658-665

25. García, A. M., A. Kun, O. Calero, M. Medina, and M. Calero. (2018). An Overview of the Role of Lipofuscin in Age-Related Neurodegeneration. Front. Neurosci, 12:464.

26. Vekshin, N.L., dan M.S. Frolova. (2018). Formation and Destruction of Thermo Lipofuscin in Mitochondria. Biochem Anal Biochem, 7: 357.

27. Ahmad, Z., dan Damayanti. (2018). Skin Aging: Pathophysiology and Clinical Manifestation. Periodical of Dermatology and Venereology, 30(3): 208-215 